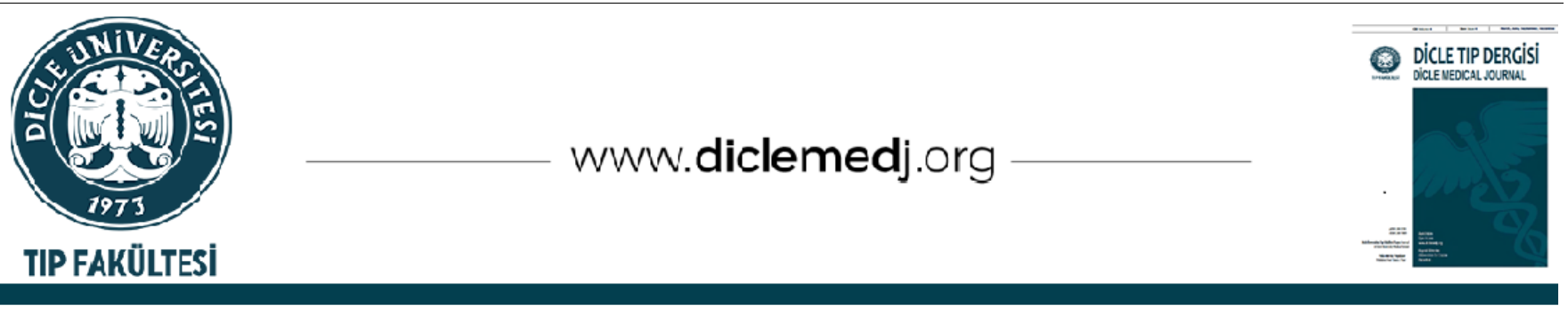

Original Article / Özgün Araştırma

\title{
The reasons for conversion from laparoscopic appendectomy to open surgery in children: the first experience on 100 cases in a single center
}

\author{
Ali Erdal Karakaya ${ }^{D}{ }_{1}$, Ahmet Gökhan Güler ${ }^{D}{ }_{1}$, Ahmet Burak Doğan ${ }^{D} 1_{1}$, Mehmet Fatih Yazar ${ }^{\left(D_{1}\right.}$ \\ 1 Sütçü İmam University School of Medicine Department of Pediatric Surgery, Kahramanmaras, Turkey
}

Received: 15.09.2020; Revised: 11.01.2021; Accepted: 27.01.2021

\begin{abstract}
Objective: This study aimed to discuss the reasons for conversion in light of the literature and reduce any unnecessary conversion to open procedure, according to our clinic's results during the learning curve.

Methods: A retrospective review was performed on 100 patients who had a laparoscopic appendectomy in our clinic between September 2014 and August 2019. The patients who had a laparoscopic appendectomy were evaluated for conversion to open procedure by reviewing the age, gender, white blood cell count (WBC), and surgical findings (location of the appendix, perforation status, peritonitis). Laparoscopy was performed through two ports.

Results: The age average of 100 patients, including 63 males who have undergone a laparoscopic appendectomy, was $10.86 \pm 3.78$ years. The laparoscopic technique was converted to open in nine children. WBC ratio of the patients was significantly higher in converted procedures. Among the procedures converted to open appendectomy, three patients presented retrocecal appendix placement; two patients presented retrocecal placement and perforation and diffuse peritonitis; three patients presented perforation and diffuse peritonitis, and one patient presented uncontrolled bleeding.

Conclusion: The use of laparoscopic appendectomy has just increased in Pediatric Surgery clinics along with some factors that affect the conversion to open procedure. WBC ratio was significantly higher in converted procedures. When study results are reviewed from this perspective, perforation, diffuse peritonitis, and the appendix's retrocecal location are the most significant independent indicators for conversion from laparotomic procedure to open procedure.
\end{abstract}

Keywords: Conversion, Laparoscopic Appendectomy, Children. Open Surgery

DOI: 10.5798/dicletip.887415

Correspondence / Yazışma Adresi: Ali Erdal Karakaya, Sütçü Imam University School of Medicine Department of Pediatric Surgery, Kahramanmaras, Turkeye-mail: dralierdal@yahoo.com 


\section{Çocuklarda Laparoskopik Apendektomiden Açık Cerrahiye Geçiş Nedenleri: İlk 100 Vaka Deneyimi}

Öz

Amaç: Bu çalışmanın amacı, öğrenme eğrisi sürecinde kliniğimizin Laparoskopik Apendektomi sonuçlarına göre, dönüşümün nedenlerini literatür ışığında tartışmak ve gereksiz açık prosedüre dönüşümü azaltmaktır.

Yöntemler: Eylül 2014-Ağustos 2019 tarihleri arasında kliniğimizde akut apandisit tanısı ile laparoskopik apendektomi yapılan 100 hasta retrospektif olarak incelendi. Laparoskopik apendektomi yapılan hastalar yaş, cinsiyet, lökosit sayımı (WBC), cerrahi bulgular (apendiksin yeri, perforasyon durumu, peritonit) açısından değerlendirildi. Hastalara iki port ile girilerek laparoskopi yapıldı.

Bulgular: Laparoskopik apendektomi yapılan 63' ü erkek 100 hastanın yaş ortalaması $10.86 \pm 3.78$ yaş idi. Dokuz hastada laparoskopik işlemden açık işleme dönüldü. Hastaların WBC oranı dönüştürülmüş işlemlerde anlamlı olarak daha yüksekti. Açık apendektomiye dönüștürülen 3 hastada apendiks retroçekal yerleşimli idi. 2 hasta retroçekal apendiksin yanı sıra diffüz peritonit, 3 hastada ise yaygın peritonit vardı. Bir hastada kontrol edilemeyen kanama nedeniyle açığa geçildi.

Sonuç: Çocuk Cerrahisi kliniklerinde laparoskopik apendektomi kullanımı artmıştır ve açı prosedüre dönüşümü etkileyen bazı faktörler vardır. Açığa dönüştürülen prosedürlerde WBC oranı önemli ölçüde daha yüksekti. Çalışma sonuçları bu açıdan incelendiğinde, apendiksin retroçekal yerleşimi, perforasyon ve yaygın peritonit laparotomik prosedürden açık prosedüre dönüşüm için en önemli bağımsız göstergelerdir.

Anahtar kelimeler: Geçiş, Laparoskopik Apendektomi, Çocuklar, Açık Cerrahi.

\section{INTRODUCTION}

Open Appendectomy (OA) is the most common surgical procedure in practice ${ }^{1}$. Laparoscopic appendectomy (LA) was first identified by Semm in $1983^{2}$ and has been widely used to treat acute appendicitis due to some advantages like providing a better view, rapid postoperative recovery, less postoperative pain, less intraabdominal adhesions, and better cosmetic results ${ }^{3}$.

Conversion to open procedure (COP) during LA may occur due to the following conditions: 4,5 , male gender ${ }^{5}$, advanced age $\mathrm{e}^{5-7}$, the surgeon's insufficient experience on laparoscopy, diffuse, peritonitis, intraoperative complications during LA or insecure laparoscopic procedure conditions considered by the surgeon ${ }^{8,9}$. COP causes prolongation of the surgery period and increases the medical costs by causing an increase in hospitalization period and surgical site infection. Also, laparoscopic surgery benefits such as less intraabdominal adhesions and less hospitalization period disappears ${ }^{8,9}$.
Although many articles exist on indications for COP13-8, there is a limited number of manuscripts evaluating the reasons for conversion in pediatric patients9.

The present study's objective was to discuss the conversion reasons along with the literature and find ways to reduce unnecessary conversions based on laparoscopic appendectomy results of our clinic at the learning curve process.

\section{METHODS}

After approval of the Ethical Committee (Kahramanmaraş Sütçü Imam University Ethical Committee, approval no: 2020/01/22- issue number: 17), 100 patients who had LA due to diagnosis of acute appendicitis in our clinic between September 2014 and August 2019 were reviewed retrospectively. The data was obtained through patient files and computer records, patient discharge reports, Pediatric Surgery clinic monitoring form, and observation papers. This retrospective study included minor patients who have undergone appendectomy for symptomatic reasons. The patients with insufficient data and 
incidental appendectomy were excluded. Physical examination was performed according to radiological methods and verified through cytological examination. The cases that had LA were evaluated for conversion to open procedure by reviewing the age, gender, white blood cell (WBC), and surgical findings (location of the appendix, perforation status, peritonitis).

\section{Surgical Technique}

All patients were exposed to general anesthesia during the surgery. The surgical site was cleared by $1 \%$ povidone-iodine after the anesthesia procedure. The left arm was combined with the body at a supine position, and the procedure was initiated. Following a supraumbilical incision of one centimeter, a $10 \mathrm{~mm}$ bladeless trocar was inserted into the abdomen, and the intraabdominal cavity was inflated with $\mathrm{CO} 2$ between 8 to $12 \mathrm{mmHg}$. After insertion of a $10 \mathrm{~mm}$ trocar, a 300 optic camera was placed. Then, a $5 \mathrm{~mm}$ trocar was placed on the left lower quadrant. The patient was positioned at a 150 Trendelenburg position with a slope of 150 . The appendix was explored after the intestines were moved away, and acute appendicitis was observed; the appendix was hung by with $2 / 0$ prolene inserted through the green-colored 5cc syringe needle inserted into the right lower quadrant, and mesoappendix was cut through energy devices (Maryland Ligasure Covidien, Boulder, co). The appendix was tied up by $2 / 0$ vicryl twice, and the appendix was cut by ligasure over the clamp. Then, it was taken into the endobag and taken out of the body along the umbilicus incision. A drainage catheter was placed into the appendicular compartment depending on the presence of abscess formation or the inflammation's severity. The skin was sutured, and the procedure was terminated. Two ports were used in all patients.

\section{Statistical Analysis}

The data analysis was performed through Package for the Social Sciences 17.0(SPSS, Armonk, New York, IL, USA) software. The distribution of continuous data was assessed with the KolmogorovSmirnov test. The variables were expressed in mean, minimum-maximum, and percent. To compare parameters between the two groups was used independent sample t-test and chi-square test.
Factors related to patient conversion were evaluated with Spearman's rho test. The contribution to converting variables determined to be related to patient conversion was evaluated with logistic regression analysis. A value of $p<0.05$ was accepted as statistically significant.

\section{RESULTS}

In the study period, 347 children underwent appendectomy with open technique and 100 children with laparoscopic technique. The age average of the LA patients was $10.86 \pm 3.78$ years (min-max: 3-17 years). It was detected that 63 patients were male, and the procedure was converted to an open procedure in 9 patients (Table $1)$. The patients were divided into two groups regarding the ultimate operation technique at the end of the procedures. While the groups were similar in terms of gender $(p=0.197)$, the WBC values of the patients who required conversion to open surgery were found to be significantly higher than those who had laparoscopically operated $(\mathrm{p}<0.001)$. It was detected that the laparoscopic procedure was converted to an open procedure in 3 patients because the dissection was found unsafe due to retrocecal and subserous location of the appendix; the laparoscopic procedure was converted to an open procedure in 2 patients because of retrocecal appendix location, perforation and diffuse peritonitis, and perforation and diffuse peritonitis in 3 patients. Since energy devices could not stop bleeding from the appendicular artery and hematoma in the mesoappendix developed in a patient, and the bleeding, the procedure was converted to open surgery in one patient (Table 2). Two surgeons have not performed conversion after case 20 whereas the third surgeon have not converted the surgery after case 35 . Every surgeon made equal conversions in terms of number It was detected that the 9th patient (a 13-year-old girl) has recently had a menstrual period; abdominal pain was considered as menstrual cycle period; the patient referred to the clinic after seven days following onset of the symptoms; white blood cell count was 22450/mm3; physical examination revealed diffuse abdominal tenderness, significant defense, and rebound on the right lower quadrant, tachycardia $(127 / \mathrm{min})$ and fever $\left(38.7^{\circ} \mathrm{C}\right)$ with septic findings. The plastron has been detected in 
the laparoscopic exploration; however, omentum has not surrounded the lesion, and there was a purulent fluid in the pelvic region. Since there was not a complete plastron formation and septic findings were prominent, continuation to the operation was decided in the same session; the procedure was performed without any complication through a lower-midline incision surrounding the umbilicus rather than Rockey-Davis incision done on other patients. Mean WBC count of $16555.55 \pm 4262.07 / \mathrm{mm} 3$ in the patients whose procedures were converted to open procedure, and there was an association between WBC count and conversion rate ( $\mathrm{r}: 0.212, \mathrm{p}=0.034$ ).

Table I: Demographic characteristics, preoperative and postoperative findings of laparoscopic appendectomy patients $(n=100)$

\begin{tabular}{|ll|}
\hline Age, year & Median \pm SD \\
Gender (Boy) & $10.86 \pm 3.78$ \\
Leukocytes(WBC) & $12428.35 \pm 3163.31$ \\
Histological data & \\
Acut & $42(42.0 \%)$ \\
Phlegmoneus & $38(38.0 \%)$ \\
Gangreneus & $12(12.0 \%)$ \\
Perforated & $8(8.0 \%)$ \\
Peritonitis & $91(91.0 \%)$ \\
No & \\
Limited & $68(68.0 \%)$ \\
\hline
\end{tabular}

Table II: Comparison demographic characteristics, preoperative and postoperative findings according to the groups

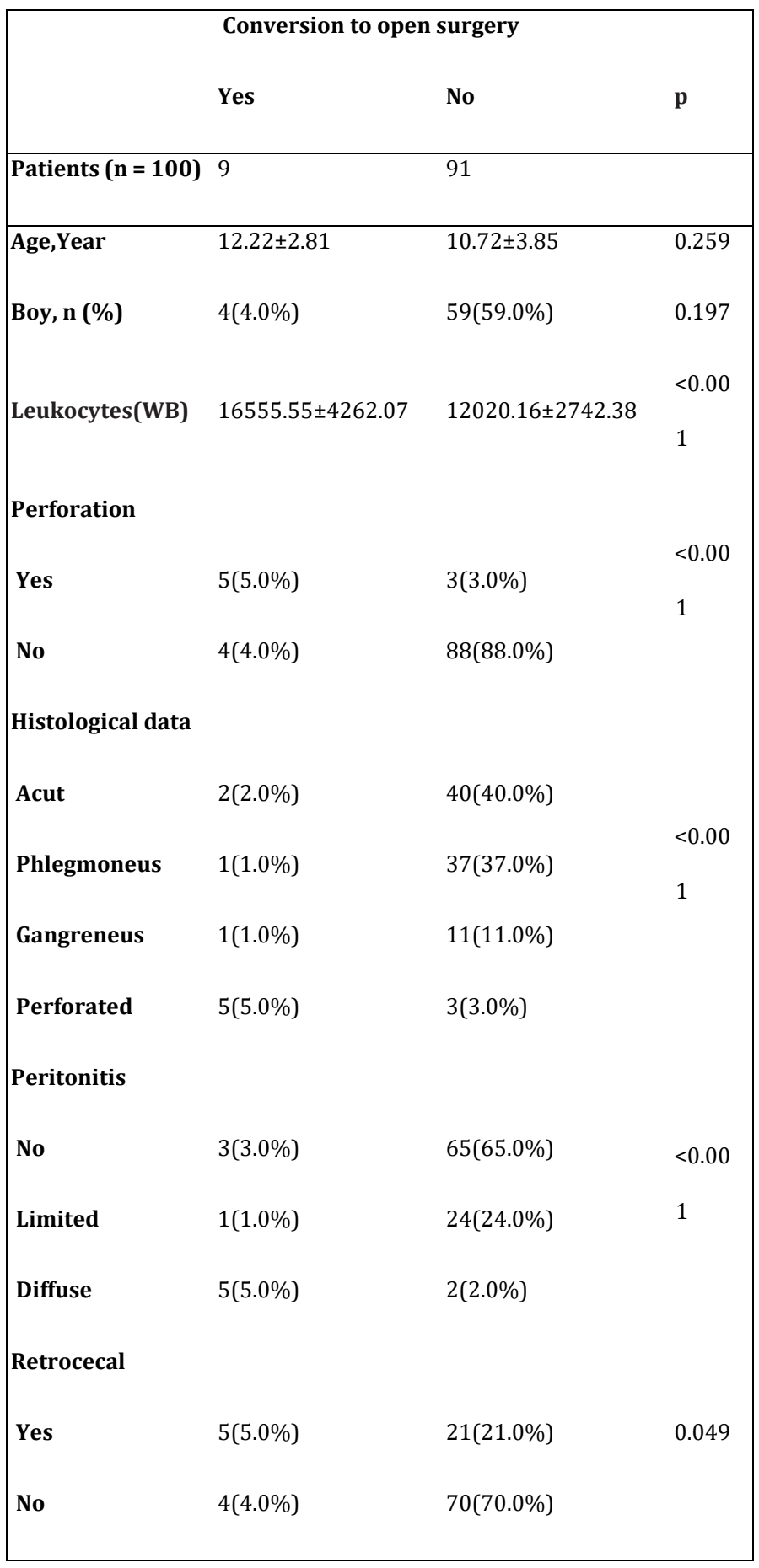

There was not any association between age, gender, and COP; however, a significant relation was detected between COP and retrocecal location of the appendix ( $\mathrm{r}: 0.214, \mathrm{p}=0.032)$, 
diffuse peritonitis ( $\mathrm{r}: 0.426, \mathrm{p}<0.001)$, and perforation ( $\mathrm{r}: 0.391, \mathrm{p}<0.001)$ (Table 3).

Table III: The factors affecting development of conversion

\begin{tabular}{|lll|}
\hline \multicolumn{2}{|c|}{$\mathrm{r}$} & $\mathrm{P}$ \\
\hline Gender & 0.121 & 0.231 \\
& 0.114 & 0.259 \\
Leukocytes(WBC) & $0.212^{*}$ & 0.034 \\
Histopathology (perforated) & $0.391^{* *}$ & $<0.001$ \\
Peritonitis & & \\
Retrocecal Appendicitis & $0.426^{* *}$ & $<0.001$ \\
& & \\
& & \\
*Corelation is significant at the 0.05 level (2-tailed) & \\
** Corelation is significant at the 0.01 level (2-tailed) & \\
\hline
\end{tabular}

In the multivariate analysis model, the predictive risk was determined for the variables predicting the probability of COP. Perforation and retrocecal location were detected as important independent determinants for COP (Table 4).

Table IV: Predictors of conversion development

\begin{tabular}{|c|c|c|c|c|}
\hline $\begin{array}{l}\text { İndependent } \\
\text { Variables }\end{array}$ & Groups & $\mathbf{n}$ & OR (CI 95\%) & $\mathbf{p}$ \\
\hline \multirow{3}{*}{ Peritonitis } & Yes (ref) & 9 & $6.214(2.21-11.57)$ & \multirow{3}{*}{0.001} \\
\hline & & & & \\
\hline & No & 91 & 1.00 & \\
\hline \multirow{3}{*}{ Perforation } & Yes (ref) & 8 & $5.576(1.17-10.17)$ & \multirow{3}{*}{0.006} \\
\hline & & & & \\
\hline & No & 92 & 1.00 & \\
\hline \multirow{3}{*}{ Retrocecal } & Yes (ref) & 26 & $2.304(1.20-5.07)$ & \multirow{3}{*}{0.042} \\
\hline & & & & \\
\hline & No & 74 & 1.00 & \\
\hline
\end{tabular}

\section{DISCUSSION}

It has been reported that two-port LA provides better angulation and ease in the procedure compared to the traditional one-port and threeport LA process ${ }^{10}$. In a study by Dönmez et al., They stated that in the two-port technique, the percutaneous organ holding device functions like a gripper and that postoperative pain and scarring are minimized with the help of such devices ${ }^{11}$. In our study, $2 / 0$ prolene advanced transabdominal through a 5cc injector needle was used as an organ holder.

Since laparoscopic appendectomy has widely used in adult patients, it is the most common surgical procedure performed by pediatric surgeons ${ }^{9}$. Although the experience improved in laparoscopic surgery procedures, conversion from laparoscopic surgery to open procedure may be required to prevent the patient's damage when the anatomy cannot be revealed entirely, bleeding appears, or sufficient view cannot be achieved ${ }^{5-8}$. A study reported that COP during LA significantly increased the costs; 9,12 believe that if the reasons for conversion from laparoscopic procedure to open appendectomy are detected, unnecessary costs may be prevented.

Although many studies define the factors that affect conversion to open surgery in adult patients1,3-8, a limited number of studies are performed on pediatric patients ${ }^{9}$. Male gender, elderliness (in the adult population), bleeding disorders, obesity, SIRS (Systemic Inflammatory Response Syndrome), or sepsis were suggested as risk factors for conversion to open surgery ${ }^{4-9}$. Johnson et al. reported an association between conversion to open procedure and male gender, advanced age, and complicated appendicitis (abscess or peritonitis) ${ }^{9}$. There was no association detected between conversion to open procedure and age and gender in the present study. The main underlying cause may be the limited number of patients with the first 100 patients enrolled in 
the present study. We believe that a larger patient number and age and gender factors may be significant.

WBC levels of the patients whose procedures were converted to open appendectomy were significantly higher than those who had laparoscopic surgery. In correlation analysis, an association was confirmed between conversion to open surgery and WBC levels. However, the regression analysis revealed that WBC levels are not predictive of the probability of COP. Elikashvilli et al. stated in their study conducted on pediatric acute appendicitis cases that WBC may contribute to appendicitis diagnosis, but it cannot be used as a tool for final diagnosis ${ }^{13}$. The outcomes of the present study are in line with the literature from this aspect.

The factors related to conversion to open surgery in pediatric patients were evaluated in a limited number of studies, and one of the most comprehensive studies has been recently published9. Although the present study's main objective was to evaluate the association between conversion to open procedure and hospital factors, some factors indicating the association between operational findings and conversion to open procedure were reported. In this context, peritonitis's existence increased the possibility of conversion to open procedure by 6.72-folds, whereas pericecal abscess increases by 14.3 -folds ${ }^{9}$. In line with the literature, we concluded in the present study that independent indicators for conversion to open procedure include diffuse peritonitis (6.214-folds), perforation (5.576-fold), and retrocecal location (2.304-fold).

Laparoscopic appendectomy has newly widened in Pediatric Surgery clinics, and some factors affect the conversion to open procedure. When study results are reviewed from this perspective, perforation, diffuse peritonitis, and the appendix's retrocecal location are the most significant independent indicators for conversion to open procedure.
The limited number of patients on appendicitis, which is common in children in different months and seasons ${ }^{14}$, is also among the reasons for limitation. Besides, the study was retrospective, patients and groups were not selected equally, and the number was limited.

\section{CONCLUSION}

While conversion of laparoscopic appendectomy to an open operation is necessary at times, multiple factors affect the frequency of conversion. It would be beneficial to conduct prospective studies with more patients to reveal the factors more clearly.

Ethical Committee Approval: After approval of the Ethical Committee (Kahramanmaraş Sütçü Imam University Ethical Committee, approval no: 2020/01/22- issue number: 17).

Declaration of Conflicting Interests: The authors declare that they have no conflict of interest.

Financial Disclosure: No financial support was received.

\section{REFERENCES}

1. Masurkar AA. Laparoscopic Trans-Abdominal Retromuscular (TARM) Repair for Ventral Hernia: A Novel, Low-Cost Technique for Sublay and Posterior Component Separation. World J Surg. 2020; 44: 1081-5.

2. Semm K. Endoscopic appendectomy. Endoscopy.1983; 15: 59-64.

3. Dumas RP, Subramanian M, Hodgman E, et al. Laparoscopic Appendectomy: A Report on 1164 Operations at a Single-Institution, Safety-Net Hospital. Am Surg. 2018; 84: 1110-6.

4. Ruiz-Patiño A, Rey S, Molina G, et al. Costeffectiveness of laparoscopic versus open appendectomy in developing nations: a Colombian analysis. J Surg Res. 2018; 224: 33-7.

5. Andert A, Alizai HP, Klink CD, et al. Risk factors for morbidity after appendectomy. Langenbecks Arch Surg. 2017; 402: 987-93. 
6. Gupta N, Machado-Aranda D, Bennett $\mathrm{K}$, et al. Identification of preoperative risk factors associated with the conversion of laparoscopic to open appendectomies. Int Surg. 2013; 98: 334-9.

7. Abe T, Nagaie T, Miyazaki M, et al. Risk factors of converting to laparotomy in laparoscopic appendectomy for acute appendicitis. Clin Exp Gastroenterol. 2013; 6: 109-14.

8. Finnerty BM, $\mathrm{Wu} \mathrm{X}$, Giambrone GP, et al. Conversion to open in laparoscopic appendectomy: A cohort analysis of risk factors and outcomes. Int J Surg. 2017; 40: 169-75.

9. Johnson KN, Linnaus M, Notrica DM. Conversion from laparoscopic to open appendectomy: decreased risk at dedicated children's hospitals. Pediatr Surg Int. 2018; 34: 873-7.

10. Gulpinar K, Ozdemir S, Ozis SE, et al. Single incision laparoscopic cholecystectomy by using a 2 $\mathrm{mm}$ a traumatic grasper without trocar. HPB Surg. 2011; 2011: 7613-15.
11. Donmez T, Sunamak O, Ferahman S, et al. Twoport laparoscopic appendectomy with the help of a needle grasper: better cosmetic results and fewer trocars than conventional laparoscopic appendectomy. Videosurgery Miniinv. 2016; 11: 105-10 .

12. Michailidou M, Goldstein SD, Sacco Casamassima $M G$, et al. Laparoscopic versus open appendectomy in children: the effect of surgical technique on healthcare costs. Am J Surg. 2015; 210: 270-5.

13. Elikashvili I, Tay ET, Tsung JW. The effect of point of care ultrasonography on emergency department length of stay and computed tomography utilization in children with suspected appendicitis. Acad Emerg Med. 2014; 21: 163-70.

14. Arslan S, Aydogdu B, Arslan MS, et al. Analysis of Risk Factors for Appendicitis in Children: A Multicenter Epidemiological Study. Dicle Med J. 2016; 43: 556-60. 